\title{
STATE AND FEDERAL APPROACHES TO HEALTH REFORM: WHAT WORKS FOR THE WORKING POOR?
}

\author{
Ellen Meara \\ Meredith Rosenthal \\ Anna Sinaiko \\ Katherine Baicker \\ Working Paper 14125 \\ http://www.nber.org/papers/w14125
NATIONAL BUREAU OF ECONOMIC RESEARCH
1050 Massachusetts Avenue
Cambridge, MA 02138
June 2008

We are grateful to participants of the 2007 Frontiers in Health Policy Research Meetings for helpful comments and suggestions on this paper. The views expressed herein are those of the author(s) and do not necessarily reflect the views of the National Bureau of Economic Research.

NBER working papers are circulated for discussion and comment purposes. They have not been peerreviewed or been subject to the review by the NBER Board of Directors that accompanies official NBER publications.

(C) 2008 by Ellen Meara, Meredith Rosenthal, Anna Sinaiko, and Katherine Baicker. All rights reserved. Short sections of text, not to exceed two paragraphs, may be quoted without explicit permission provided that full credit, including $(\mathcal{C}$ notice, is given to the source. 
State and Federal Approaches to Health Reform: What Works for the Working Poor? Ellen Meara, Meredith Rosenthal, Anna Sinaiko, and Katherine Baicker

NBER Working Paper No. 14125

June 2008

JEL No. I1,I11,J3

\begin{abstract}
We compare and contrast the labor market and distributional impact of three common approaches to state and federal health insurance expansion: public insurance expansions, refundable tax credits for low income people, and employer and individual mandates. We draw on existing estimates from the literature and individual-level data on the non-institutionalized population aged 64 and younger from the 2005 Current Population Survey to estimate how each approach affects (1) the number of people insured; (2) private and public health spending; (3) employment and wages; and (4) the distribution of subsidies across families based on income in relation to the federal poverty level and work status of adult family members. Employer mandates expand coverage to the largest number of previously insured relative to public insurance expansions and individual tax credits, but with potentially negative labor market consequences. Medicaid expansions could achieve moderate reductions in the share of the uninsured with neutral labor market consequences, and by definition, they expand coverage to the poorest groups regardless of work status. Tax credits extend coverage to relatively few uninsured, but with neutral effects on the labor market. Both Medicaid expansions and tax credits offer moderate redistribution to previously insured individuals who are poor or near-poor. None of the three policies significantly expand insurance coverage among poor working families. Our findings suggest that no single approach helps the working poor in exactly the ways policy makers might hope. To the extent that states are motivated to help the uninsured in poor working families, health reforms must find ways to include those unlikely to take up optional policies, and states must address the challenge of the many uninsured likely to be excluded from policies based on part-time work status, firm size, or immigration status.,
\end{abstract}

Ellen Meara

Department of Health Care Policy

Harvard Medical School

180 Longwood Avenue

Boston, MA 02115-5899

and NBER

meara@hcp.med.harvard.edu

Meredith Rosenthal

Department of Health Policy and Management

Harvard School of Public Health

677 Huntington Avenue

Boston, MA 02115

mrosenth@hsph.harvard.edu
Anna Sinaiko

Harvard University

Department of Health Care Policy

Boston, MA 02118

sinaiko@fas.harvard.edu

Katherine Baicker

Professor of Health Economics

Department of Health Policy and Management

Harvard School of Public Health

677 Huntington Avenue

Boston, MA 02115

and NBER

kbaicker@hsph.harvard.edu 


\section{Introduction}

It is a well-worn fact that over 46 million people in America now lack health insurance. Less well-known is that $80 \%$ of uninsured individuals live in families with at least one worker, but the vast majority of these families have incomes under 300\% of the federal poverty level (Kaiser Family Foundation, 2004). Although the national appetite for large-scale reform has waned since President Clinton's failed attempt at broad health system reform, rising health insurance costs and declining rates of employer coverage have motivated a wave of state legislative proposals to expand health insurance coverage, particularly among this population of low-income workers. As of February 2008, three states had enacted reforms to achieve near universal coverage, and twelve more states have proposed comprehensive reforms or formed commissions to recommend insurance expansion proposals (Kaiser Family Foundation, 2008). These proposals run the gamut from employer mandates to Medicaid expansions to state-sponsored insurance pools. The April 2006 health reform legislation in Massachusetts has attracted particular attention; its objective is to provide coverage to every state resident through the combination of an individual mandate, employer requirements, redirection of existing Medicaid funds, and the creation of a new insurance infrastructure. Although it will take many years to fully evaluate the effect of this and other state programs, and approaches that work well in some states may not work in others (Glied and Gould, 2005), it is still possible to draw broad lessons about the likely effects of different approaches (McDonough et al., 2006). ${ }^{1}$ In choosing among alternative policies, it is important to evaluate their effects not just on the number of people covered by health insurance, but also on public and private expenditures and on labor market outcomes such as employment and wages, outcomes of particular importance to workers in poor and near-poor families. Finally, when comparing the tradeoffs between policies, one should consider the redistributive benefits of insurance expansions that make care more affordable for low-income individuals.

In this paper, we evaluate the likely effects of three prototypical approaches to expanding health insurance coverage: public insurance expansions, refundable tax credits for low-income people, and employer and individual mandates. We draw on existing estimates from the literature and individual-level data from the 2005 Current Population Survey to estimate how each approach affects (1) the number of people insured; (2) private and public health spending;

\footnotetext{
${ }^{1}$ Massachusetts had several idiosyncratic characteristics that fostered a large-scale reform. It had fewer uninsured individuals than most states and greater revenue available to fund subsidized insurance coverage in the short term, and a political climate that was conducive to the legislation.
} 
(3) employment and wages; and (4) the distribution of subsidies across families based on income and work status.

These approaches have substantially different public and private costs that must be considered in addition to differences in the number and composition of the newly insured. For example, although employer mandates are likely to increase insurance rates among the near-poor substantially, they do so at the cost of reduced employment for low-wage workers. Similarly, Medicaid expansions are likely to increase insurance coverage more modestly without reducing employment but entail social costs because they require additional public revenue, typically obtained through taxes that distort the behavior of individuals and firms. Furthermore, the distributional consequences of insurance coverage and redistribution of resources toward individuals whose insurance status may not change under reforms is one dimension that decision makers may wish to consider but is often overlooked. States and the Federal government should take all of these dimensions into account, not simply the number newly insured.

\section{Three Common Approaches}

Table 1 outlines three frequently considered approaches to covering those who are uninsured. First, employer mandates typically require employers either to provide sufficiently generous insurance to employees or to pay an assessment. The Massachusetts plan is an example of an employer mandate coupled with an individual mandate to purchase insurance, enforced through the tax system. Second, Medicaid expansions extend public insurance coverage to individuals with certain income or demographic characteristics. Some proposals also change the nature of the Medicaid entitlement, such as converting the publicly provided insurance policy to a voucher that recipients can use to purchase private insurance. Third, tax credits can subsidize the purchase of private health insurance coverage, are usually refundable, and often are restricted to the nongroup market (markets in which individuals purchase coverage without sponsorship of an employer, union, or other organization). Such tax credits have been proposed in President Bush's past budgets. Notably, mandates, public insurance expansions, tax credits, or some combination of the three have been put forth by each of the three leading presidential candidates for the 2008 presidential election.

There are many variations on each of these proposals, often intended to make health insurance more affordable to the near-poor. For example, President Bush's fiscal year 2007 budget proposal required people to have high deductible health plans in order to collect the tax credit, encouraging the purchase of health plans with relatively low premiums but higher out-of-pocket spending. Some have suggested that combining such tax credits with other reforms would generate 
Table 1. Forms of Recent State and Federal Health Expansion Proposals

\begin{tabular}{|c|c|c|c|}
\hline Expansion & Description & Variations & $\begin{array}{l}\text { Recent Examples of } \\
\text { These Initiatives }\end{array}$ \\
\hline $\begin{array}{l}\text { Employer } \\
\text { mandates }\end{array}$ & $\begin{array}{l}\text { - Mandate that } \\
\text { employers either } \\
\text { provide health } \\
\text { insurance benefits to } \\
\text { employees or pay into } \\
\text { a state-run program } \\
\text { that provides health } \\
\text { benefits to these } \\
\text { workers } \\
\text { - Often only applies to } \\
\text { firms with a minimum } \\
\text { number of workers }\end{array}$ & $\begin{array}{l}\text { - May or may not be } \\
\text { coupled with a mandate } \\
\text { that individuals purchase } \\
\text { health insurance } \\
\text { - Can be coupled with a } \\
\text { state- managed health } \\
\text { insurance purchasing } \\
\text { pool for unemployed, } \\
\text { self-employed, and/or } \\
\text { workers at small firms to } \\
\text { purchase private health } \\
\text { insurance plans } \\
\text { - Premiums often } \\
\text { subsidized by the state } \\
\text { according to a sliding } \\
\text { scale based on family } \\
\text { income }\end{array}$ & $\begin{array}{l}\text { - California, } \\
\text { Massachusetts, } \\
\text { Michigan, New } \\
\text { Jersey, New York, } \\
\text { Ohio } \\
\text { - } 2008 \text { Presidential } \\
\text { primary proposals } \\
\text { (Clinton \& } \\
\text { Obama) }\end{array}$ \\
\hline $\begin{array}{l}\text { Medicaid or } \\
\text { other publicly } \\
\text { provided } \\
\text { insurance } \\
\text { expansion }\end{array}$ & $\begin{array}{l}\text { Expand eligibility for } \\
\text { public health insurance } \\
\text { under Medicaid or S- } \\
\text { CHIP }^{\mathrm{b}} \text { program to } \\
\text { children and adults }\end{array}$ & $\begin{array}{l}\text { - May include a buy-in } \\
\text { option for state residents } \\
\text { who donÕt næet income } \\
\text { requirements } \\
\text { - Can allow increased role } \\
\text { for private market } \\
\text { through offer of managed } \\
\text { care plans or subsidized } \\
\text { purchase of private } \\
\text { coverage. }\end{array}$ & $\begin{array}{l}\text { - Illinois, } \\
\text { Massachusetts, } \\
\text { Oregon, } \\
\text { Tennessee, } \\
\text { Wisconsin } \\
\text { - Maine (Dirigo), } \\
\text { Vermont } \\
\text { (Catamount } \\
\text { Health), } \\
\text { Pennsylvania } \\
\text { (AdultBasic) } \\
\text { 2008 Presidential } \\
\text { primary health } \\
\text { plan proposals } \\
\text { (Clinton \& } \\
\text { Obama) }\end{array}$ \\
\hline Tax credits & $\begin{array}{l}\text { - Tax credits for } \\
\text { purchase of a health } \\
\text { plan in the non-group } \\
\text { market } \\
\text { - Tax credit may be } \\
\text { refundable }\end{array}$ & $\begin{array}{l}\text { - May require purchase of } \\
\text { a high-deductible health } \\
\text { plan that meets a } \\
\text { minimum deductible } \\
\text { threshold } \\
\text { - May also be extended to } \\
\text { group health insurance } \\
\text { products }\end{array}$ & $\begin{array}{l}\text { - } \text { Bush } \\
\text { administration } \\
\text { - } 2008 \text { presidential } \\
\text { primary health } \\
\text { plan proposals } \\
\text { (McCain \& } \\
\text { Clinton) }\end{array}$ \\
\hline
\end{tabular}

\footnotetext{
a Although many state initiatives to reform their Medicaid programs may alter the eligible population, we focus on major expansions in Medicaid eligibility. ${ }^{\text {b }}$ S-CHIP = State Children@̃ Health Insurance Program.
} 
the greatest potential increase in coverage, and tax credits more generally have garnered bipartisan support (Cogan, Hubbard, and Kessler, 2005; Etheredge, 2006). ${ }^{2}$ Insurance pools are another strategy used in many states to provide lower-cost options for people without employer-sponsored coverage. Often they are coupled with a subsidy (or tax credit) to make premiums more affordable, or with a mandate or public insurance expansion.

This list is by no means exhaustive, and two other approaches warrant particular mention. Many states have passed legislation to allow adult children to remain on their parents' insurance policies, typically until age 25, and until 30 in New Jersey (National Conference of State Legislatures, 2006). These provisions affect a relatively small share of uninsured individuals but can substantially affect the non-group health insurance market. Finally, many states are experimenting with Medicaid waivers. Most waivers are designed primarily to lower costs (through methods such as increased cost-sharing, limited benefits, or an increased role of managed care), but waivers have also allowed more comprehensive Medicaid reform. For example, in 2005, Florida employed a waiver to implement a defined contribution approach where Medicaid beneficiaries can use their statefinanced risk-adjusted premium to enroll in a Medicaid managed care plan or to subsidize purchase of private employer-sponsored or individual-market coverage. Successful cost-saving waivers could enable states to insure more people without expanding Medicaid budgets, particularly if they foster a better-functioning individual insurance market.

Evaluating the likely effects of these proposals is a difficult empirical exercise. Few of the reforms shown in Table 1 have been implemented, and many of their consequences remain unknown. Supporters of each proposal often argue that theirs will reduce the number of uninsured individuals at the lowest cost, while pointing out the potential negative consequences of the others. For example, Medicaid expansions may encourage employers to drop private coverage as beneficiaries take advantage of lower premiums or more comprehensive benefits, known as 'crowd out' (Cutler and Gruber, 1996; ShoreSheppard et al., 2000); employer mandates may lower wages and increase unemployment. Existing evidence, when available, offers some support for both sides of the debates (Lo Sasso, and Buchmueller, 2004). Any assessment of these health insurance reforms must consider the effects on both health insurance coverage and labor markets, especially for low-wage workers, to get a complete picture of their distributional implications.

\footnotetext{
${ }^{2}$ We explicitly consider the availability of low-cost health insurance policies in simulating the effect of tax credits in alternate specifications reported in Appendix Table A4.
} 


\section{Economics of Insurance Expansion}

When comparing the effects of insurance expansions, a thorough economic analysis considers multiple factors including: the take-up of each policy (the percentage of those eligible for a policy who use it); crowd-out (the percentage of those taking up coverage who were previously insured); public and private costs of insurance expansions; effects on wages and employment in response to changing health care costs; deadweight loss imposed by raising revenue for publicly funded expansions; and the implicit or explicit redistribution inherent in each policy.

Our analysis of the labor market effects of insurance expansions builds on the literature predicting how labor market outcomes (i.e., employment, hours, and wages) change in response to mandated insurance benefits. Economic theory predicts that, when possible, employers will pass mandate costs on to employees through lower wages (Summers, 1989). Who ultimately bears the burden of any tax on wages is determined by the relative responsiveness of workers and employers, but the burden of mandated benefits also depends on how much employees value the benefits. If employees believe that benefits have value equal to or greater than the cost of providing them (and there are no institutional constraints to lowering wages), they will fully pay for the benefits with lower wages and still be as well off (Summers, 1989). Empirical evidence suggests a complete wage offset of mandated maternity benefits and workers' compensation benefits (Gruber, 1994; Gruber, and Krueger, 1991). In the case where minimum wage laws limit employers' ability to reduce wages, however, the mandate will have the same effect as an increase in the minimum wage, potentially resulting in increased unemployment. During the Clinton health plan debate, researchers used responses to minimum wage increases to estimate the effect of employer mandates on employment and projected a loss of 100,000 jobs (Klerman and Goldman, 1994). Recent empirical evidence suggests lowered employment as health care costs rise (Baicker and Levy, 2005; Baicker and Chandra, 2006).

One should note that our simulations consider only the most direct, or "partial equilibrium," effects of changing health insurance costs, but these changes could have broader effects throughout the economy, including effects on prices of goods and services sold by firms, profitability, or the way firms produce goods (such as a shift toward using more technology and fewer workers if labor costs rise). These less-direct, or "general equilibrium," effects of insurance expansions are likely to be smaller in magnitude, especially given the empirical evidence on wage and employment changes in response to mandates and health care costs (Gruber, 1994; Gruber, and Krueger, 1991). 


\section{Methods for Comparing the Proposals}

Because state initiatives are changing almost daily, we analyzed stylized versions of the three major health insurance expansion approaches. Table 2 briefly describes the relevant eligibility rules, the size of benefits such as tax credits, and other information for the three policy simulations. We modeled an employer mandate applied to full-time workers at firms with more than 25 employees, a Medicaid expansion up to $300 \%$ of the federal poverty level, and a tax credit of up to $\$ 3,000$ for families with income under $\$ 60,000$. Our analysis was restricted to the non-elderly (less than 65 years of age), non-institutionalized United States population represented in the March 2005 Current Population Survey.

We compared the effects of the three policies on both insurance and employment outcomes. First, we estimated the number of people eligible, the number predicted to take up health insurance under that policy, the fraction of them who already had insurance from another source, and the average value of the health insurance benefit for those who take it up. We then calculated changes in private spending on health insurance, changes in public spending on health insurance, and any deadweight loss arising from policies that require raising public tax revenues, or due to the implicit tax imposed by mandates that require spending on health insurance that may not be fully valued. We next estimated changes in wages, employment, and hours worked per week per newly insured person. Finally, we showed the distribution of the newly insured individuals separately by employment status (whether the head of household or spouse works) and by family poverty level (under 100\%, 100-200\%, 200-300\%, and over 300\%).

To perform these calculations, we combined estimates from the literature with our own calculations from the Current Population Survey. From the literature, we identified the take-up rate of publicly provided free coverage among various demographic groups; the rate of crowd-out; the price elasticity of demand for insurance coverage; the response of private employers to changes in employee costs and how this affects wages and employment; the estimated costs of providing private or public coverage to individuals and families; and the deadweight loss of raising public revenue. We used the Current Population Survey to calculate the number of individuals eligible for each policy based on income, family structure, and employment; and the distribution of single versus

family coverage among insured workers. A more comprehensive description of the source of parameter estimates, our general approach, and the sensitivity of our results to choice of key parameters can be found in the Technical Appendix. 


\begin{tabular}{|c|c|c|c|}
\hline & $\begin{array}{l}\text { Employer } \\
\text { Mandates }\end{array}$ & $\begin{array}{l}\text { Medicaid } \\
\text { Expansions }\end{array}$ & Tax Credits $^{\mathrm{a}}$ \\
\hline $\begin{array}{l}\text { Eligibility by } \\
\text { insurance status }\end{array}$ & $\begin{array}{l}\text { Uninsured full- } \\
\text { time workers \& } \\
\text { dependents at } \\
\text { firms with } 25 \text { or } \\
\text { more workers }\end{array}$ & $\begin{array}{l}\text { No } \\
\text { requirements }\end{array}$ & $\begin{array}{l}\text { Individuals without } \\
\text { employer-sponsored or } \\
\text { public insurance } \\
\text { coverage }\end{array}$ \\
\hline Income eligibility & $\begin{array}{l}\text { No income } \\
\text { cutoff }\end{array}$ & $\begin{array}{l}\text { Income under } \\
300 \% \text { of } \\
\text { poverty level }\end{array}$ & $\begin{array}{l}\text { Adjusted gross income: } \\
\text { Single tax filer - up to } \\
\$ 30,000 \\
\text { Other tax filer- up to } \\
\$ 40,000 \text { for individual } \\
\text { coverage, } \$ 60,000 \text { for } \\
\text { family }\end{array}$ \\
\hline Maximum benefit & $\begin{array}{l}\text { Family coverage } \\
\text { through } \\
\text { employer }\end{array}$ & $\begin{array}{l}\text { Medicaid } \\
\text { coverage }\end{array}$ & $\begin{array}{l}\$ 1,000 \text { per adult } \\
\$ 500 \text { per child } \\
\$ 3000 \text { max per family }\end{array}$ \\
\hline $\begin{array}{l}\text { Individual } \\
\text { mandate }\end{array}$ & $\begin{array}{l}\text { Simulated with } \\
\text { \& without }\end{array}$ & None & None \\
\hline \multicolumn{4}{|c|}{$\begin{array}{l}\text { a'Details of tax credit are shown in appendix table A1. } \\
\text { b This assumes no "anti-crowd-out" provisions. }\end{array}$} \\
\hline \multicolumn{4}{|c|}{ Effects on Health Insurance Coverage and Spending } \\
\hline \multicolumn{4}{|c|}{$\begin{array}{l}\text { Our simulation results, presented in Table } 3 \text {, demonstrate important differences } \\
\text { across these three insurance reform approaches. The typical Medicaid expansions } \\
\text { and tax credits are available to more people, with } 59.0 \text { million eligible (including } \\
20.8 \text { million uninsured) for Medicaid expansions and } 52.5 \text { million eligible } \\
\text { (including } 39.6 \text { million uninsured) for tax credits, and } 21.2 \text { million eligible (all } \\
\text { uninsured) for employer mandates. The scope for displacing private spending } \\
\text { with the public subsidy is likely biggest with the tax credit, since the most } \\
\text { relevant evidence from the literature suggests limited new insurance take-up in } \\
\text { response to an increase in insurance premium subsidies (Glied, Remler, and Zivin, } \\
\text { 2002; Congressional Budget Office 2005; Gruber, 2004; Marquis et al., 2004; }\end{array}$} \\
\hline
\end{tabular}


Dorn et al., 2005). ${ }^{3}$ These estimates suggest that only about 1.5 million previously uninsured individuals would gain insurance coverage with the credit. We assumed that virtually all those already purchasing insurance in the non-group market would take advantage of the credit. Thus, almost $90 \%$ of those taking up the tax credit, 11.6 million out of 13.1 million total, are likely to have had prior insurance coverage. This group reaps substantial financial benefits, however, with an average subsidy of over $\$ 1,000$ per tax filing unit, and $\$ 687$ per person. In contrast, using the $35 \%$ public insurance expansion crowd-out estimate from the literature suggests that only 2.7 million of those gaining coverage through the Medicaid expansion would have been previously insured (Cutler, and Gruber, 1996; Dubay, and Kennedy, 1996; Blumberg, Dubay, and Norton, 2000;ShoreSheppard, Buchmeueller, and Jansen, 2000). Low-income workers would also benefit from redistribution under this plan as they take up Medicaid, since employer health care costs would drop by an estimated $\$ 8.3$ billion, which would induce an increase in cash wages of the same amount.

Under employer mandates, private employer spending would rise by an estimated $\$ 40.6$ billion if employers continued to buy coverage at the typical prevailing premiums. This spending would exceed the public spending of $\$ 16.4$ billion for a Medicaid expansion and $\$ 9.0$ billion for the tax credit. In exchange for the largest increases in spending, the number of uninsured individuals would be expected to fall most with employer mandates - by 33\%, compared with $12 \%$ for Medicaid expansions and only 3.8\% for tax credits. Employer mandates would have even bigger effects on costs, insurance, and employment when coupled with individual mandates, which could, as an upper bound estimate, lower rates of uninsured by half in a world with perfect compliance. However, as Massachusetts' early experience and evidence on mandates in other settings suggest, mandates are imperfect policies and their success relies on the relative costs of compliance versus noncompliance and effective enforcement (Glied, Hartz, and Giorgi, 2008).

The social cost, or deadweight loss, of each policy would vary across approaches. Medicaid expansions would induce deadweight loss of $\$ 4.9$ billion. We estimated the deadweight loss cost of tax credits at $\$ 2.7$ billion. Finally, assuming that workers only value the health insurance mandated under an employer mandate at half of its cost, employer mandates would generate \$1.6 billion of deadweight loss because of the wedge between the total cost of compensation to employers and the total value of that compensation to workers.

\footnotetext{
${ }^{3}$ There is some variation in estimated take-up rates in the literature, discussed in these papers and in Glied et al. (2002). The number newly insured is directly proportional to the estimated elasticity of demand for non-group coverage. Thus, there would be three times as many newly insured given an elasticity of -.3 than there are in our results below that assume an elasticity of -.1.
} 
Both Medicaid expansions and the tax credit approaches yield significant redistribution of public funds to previously insured low-income individuals. Individuals dropping private coverage for Medicaid would, in aggregate, receive $\$ 5.7$ billion in the form of free Medicaid insurance. Individuals previously purchasing insurance in the non-group market would receive subsidies totaling $\$ 7.8$ billion for the purchase of that coverage. Thus, even policies that insure relatively few uninsured individuals may have great social value. Given the difficulty choosing an appropriate social welfare function that could assign relative values to redistribution at different levels and based on characteristics of the beneficiaries of redistribution, we do not explicitly model or value this change in social welfare, but we highlight the magnitude of the redistribution inherent in these two health reform approaches.

Although our simulations show that these policies would decrease the uninsured population overall, uninsurance could increase among some groups. For example, if a policy that offered tax credits was limited to purchase of coverage in the non-group market, some employers might stop offering coverage. If some workers would fail to take up the tax credit to purchase coverage, they would become newly uninsured. These effects, which we did not model, would likely be small compared to the main effects, especially if the new expansions covered only a minority of employees in any particular firm.

\section{Effects on Labor Markets}

Table 3b demonstrates that the aggregate labor market effects would be negative for the employer mandates, and to a first approximation neutral for tax credits and neutral or even positive for Medicaid expansions. As mentioned before, cash wages would drop among previously uninsured workers who received insurance under a new mandate and would rise among previously insured workers who would drop employer-sponsored coverage to take-up Medicaid benefits. In the aggregate, each $10 \%$ reduction in the number of uninsured individuals would decrease annual wages by $\$ 20.8$ billion under an employer mandate and would increase wages by $\$ 6.9$ billion under Medicaid expansions. About 235,000 fewer workers would be employed with an employer mandate (when workers' wages cannot adjust downward and workers do not fully value the mandated benefits). ${ }^{4}$ Hours worked would fall by $0.77 \%$ under mandates.

\footnotetext{
${ }^{4}$ Baicker and Levy explicitly estimate what might be considered a lower bound on the potential disemployment effects of employer mandates: they estimate the fraction of the uninsured population earning wages so low that they cannot fully adjust to higher mandated health costs because of the minimum wage, but assume that all workers fully-value the mandated benefits so that there is no disemployment for higher-wage workers. Here, we assume that workers only
} 
Comparison of Expansion Approaches

\begin{tabular}{|c|c|c|c|}
\hline & $\begin{array}{l}\text { Employer } \\
\text { Mandates }^{\mathrm{a}}\end{array}$ & $\begin{array}{l}\text { Medicaid } \\
\text { Expansions }\end{array}$ & $\begin{array}{c}\text { Tax } \\
\text { Credits }\end{array}$ \\
\hline Number of people eligible & 21.2 million & 59.0 million & 52.5 million \\
\hline Take-up by previously insured & 0 & 2.7 million & 11.6 million \\
\hline $\begin{array}{l}\text { Take-up by uninsured } \\
\text { (Reduction in uninsured) }^{c}\end{array}$ & $\begin{array}{l}\text { 14.2 million } \\
(33 \%)\end{array}$ & $\begin{array}{l}5.0 \text { million } \\
(12 \%)\end{array}$ & $\begin{array}{l}1.5 \text { million } \\
(3.4 \%)\end{array}$ \\
\hline $\begin{array}{l}\text { Average value of benefit for } \\
\text { those who take it up }\end{array}$ & $\$ 2,860$ & $\$ 2,138$ & $\$ 687$ \\
\hline $\begin{array}{l}\text { Public spending } \\
\text { Total } \\
\text { Per newly insured }\end{array}$ & $\begin{array}{l}0 \\
0\end{array}$ & $\begin{array}{l}\$ 16.4 \text { billion } \\
\quad \$ 3,289\end{array}$ & $\begin{array}{l}\$ 9.0 \text { billion } \\
\$ 6,000\end{array}$ \\
\hline $\begin{array}{l}\text { Private spending } \\
\text { Total } \\
\text { Per newly insured }\end{array}$ & $\begin{array}{l}\$ 40.6 \text { billion } \\
\quad \$ 2,860\end{array}$ & $\begin{array}{l}-\$ 8.3 \text { billion } \\
-\$ 1,664\end{array}$ & $\begin{array}{c}-\$ 6.4 \text { billion } \\
\quad-\$ 4,307\end{array}$ \\
\hline $\begin{array}{l}\text { Deadweight loss } \\
\text { Redistribution to previously } \\
\text { insured }\end{array}$ & $\$ 1.6$ billion & $\$ 4.9$ billion & $\$ 2.7$ billion \\
\hline
\end{tabular}

a- With an individual mandate, the employer and individual mandates would newly insure 21.2 million, reduce employment by $1.9 \%$, and raise private spending by $\$ 60.6$ billion. .

b- As noted in the text, the tax credits modeled here are less generous than those many others proposed in ongoing debates. Using a limit of $\$ 2500$ for individuals and $\$ 5000$ for families would yield 2.9 million newly insured at a cost of $\$ 20$ billion in new public spending. It would also redistribute $\$ 15.6$ billion to previously insured individuals taking up the credit.

c- Because empirical estimates of employers dropping offers of coverage in response to insurance expansions are negligible, these effects are not included, making the number of newly insured equal to take-up by previously uninsured. The \% change in uninsured is based on the 2005 CPS estimate of 43.0 million uninsured individuals under age 65 .

${ }^{d-}$ This represents net change in private spending, or the difference between increased spending on health insurance by newly insured and the decrease in spending by the previously insured.

partially value benefits. Disemployment effects will be proportionately higher or lower depending on this assumption. 
Table 3b.

Labor Market Effects per 10\% Reduction in Uninsured

\begin{tabular}{lccc}
\hline Change In: & $\begin{array}{c}\text { Employer } \\
\text { Mandates }\end{array}$ & $\begin{array}{c}\text { Medicaid } \\
\text { Expansions }\end{array}$ & Tax Credits \\
\hline Employed workers & $-235,000$ & & \\
$(\%)$ & $(-0.39)$ & $\mathrm{a}$ & $\mathrm{b}$ \\
Hours worked per week & -18.8 million & & \\
$(\%)$ & $(-0.77)$ & $\mathrm{a}$ & $\mathrm{b}$ \\
Annual wages & $-\$ 20.8$ billion & $\$ 6.9$ billion $^{\mathrm{a}}$ & \\
$(\%)$ & $(-0.69)$ & $(0.33)$ & $\mathrm{b}$ \\
\hline
\end{tabular}

${ }^{\mathrm{a}-}$ If falling health care costs induce employment and hours effects that equal those in Baicker and Chandra (2006) but simply operate in the opposite direction, employment would rise by 192,000 workers and hours worked per week would increase by 14 million. However, in the absence of evidence that these effects are symmetric (that the response to falling health care costs equals that for rising health care costs), we believe that these are upper bound effects and actual effects would likely be closer to zero. The change in cash wages results from wages adjusting upward for workers who drop employer-sponsored coverage to take up Medicaid.

b- Given the ambiguous sign of labor market effects accompanying tax credits, and the expectation that these are very small in magnitude, these are likely close to zero.

\section{Effects for the Working Poor}

Would poor working families benefit more from some expansion approaches than others? Table 4 suggests that under employer mandates, two-thirds of newly insured individuals would live in working families with incomes under $300 \%$ of the poverty level. By design, our Medicaid expansions target only families with income under $300 \%$ of the poverty level, and over $60 \%$ of the newly insured would be in working families. Tax credits also target individuals with low and moderate incomes. The most striking feature of Table 4, though, is the low reduction in rates of uninsurance in any of the three approaches among those living below the poverty level. For employer mandates, this occurs mainly because many individuals in these families do not work full time. The design of employer mandates could address this by extending mandates to part-time workers, but not without additional effects on wages and/or employment. Many of those eligible under the Medicaid proposal are individuals already eligible (based on income criteria) but not enrolled in Medicaid, so we assumed that the expansion would have no effect on them. This can explain why a program targeting the poor would likely cover less than one-fifth of uninsured individuals living below poverty. The tax credit would perform poorly at all income levels against the goal of reducing the number uninsured, and working families with income under $100 \%$ of the poverty level are no exception. However, this tax credit is relatively modest, and the more generous tax credits proposed by current presidential hopefuls might boost the insurance effects. 
Table 4. Distribution of Newly Insured and Percent Reduction of Uninsured Under Each Simulation by Family Income and Employment

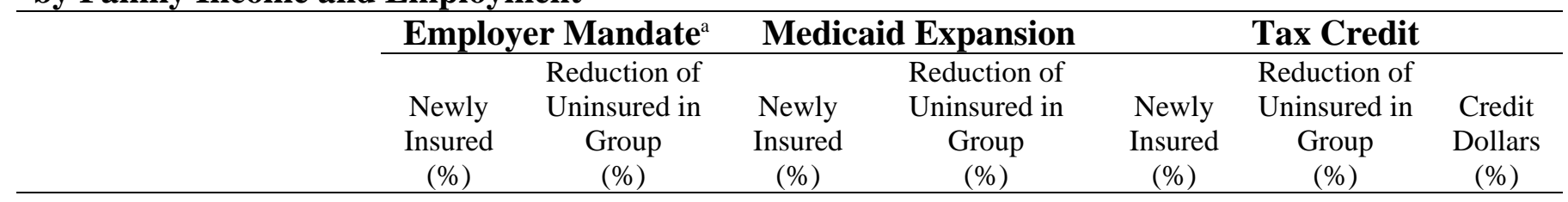

\section{Working individuals}

\& families 100\%-200\% poverty 200\%-300\% poverty

$>300 \%$ poverty

$\begin{array}{ll}12 & 12 \\ 31 & 18 \\ 24 & 20 \\ 33 & 21\end{array}$

$\begin{array}{cc}5.9 & 5.9 \\ 20 & 11 \\ 37 & 30 \\ 0 & 0\end{array}$

$\begin{array}{lll}15 & 4.6 & 5.7 \\ 25 & 4.2 & 13 \\ 11 & 2.8 & 8.8 \\ 11 & 2.8 & 21\end{array}$

\section{Non-Working}

individuals

\& families

\begin{tabular}{lllccccc}
$<100 \%$ poverty & 0 & 0 & 11 & 8.6 & 19 & 4.5 & 13 \\
$100 \%-200 \%$ poverty & 0 & 0 & 12 & 16 & 11 & 4.3 & 14 \\
200\%-300\% poverty & 0 & 0 & 14 & 31 & 4.4 & 3.0 \\
$>300 \%$ poverty & 0 & 0 & 0 & 0 & 3.3 & 2.6 & 16 \\
\hline
\end{tabular}

${ }^{a}$ The percent reduction of the uninsured presented in the table corresponds to the case in which there is no individual mandate. With an individual mandate, the percent reductions in uninsured below $100 \%$ of poverty, between $100 \%$ and $200 \%$ of poverty, between $200 \%$ and $300 \%$ of poverty, and above $300 \%$ of poverty, respectively are $18 \%$, $26 \%$, $30 \%$, and $31 \%$. 


\section{Redistribution from Health Insurance Expansions}

Although the insurance effects of health reforms would be modest without individual mandates, the redistribution implicit in insurance expansions would offer substantial increases in the well-being of low-income families. Among those purchasing insurance coverage via tax credits, the average subsidy would be about $\$ 687$ per person covered by the tax credit. Over half of the tax credit dollars, about $63 \%$, would accrue to families and individuals with income below $300 \%$ of the poverty level. A substantial share of the dollars, $46 \%$, would accrue to families with income under $200 \%$ of the poverty level. These distributional benefits would accrue to both working and non-working families.

The tax credit simulated here was based on the Bush Administration budget proposal for fiscal year 2007. This proposal was modest in generosity compared with those in current tax credit proposals. However, one could easily extend our analyses to describe the impact of a more generous tax credit, and in cases with no individual mandate, our qualitative conclusions regarding the insurance impact and general distributional consequences will remain. Because voluntary take-up of insurance in response to subsidized coverage is relatively low, the number of newly insured individuals will still be low relative to other alternatives, absent an individual mandate. ${ }^{5}$ However, the amount of redistribution achieved through the tax credits would be substantially higher under more generous tax credit scenarios.

Medicaid expansions also offer significant redistribution to families. The $\$ 8.3$ billion reduction in private spending under the Medicaid expansion would accrue to individuals either through higher wages or directly through premium reductions. The majority of individuals newly insured would be in families with children. Among those newly insured under a Medicaid expansion, many have children covered by the State Children's Health Insurance Program (data not shown). Tax credits have similar effects on families with and without children.

\section{Implications of our Analysis for Current Health Reform Initiatives}

Although our analysis focuses on stylized reform approaches, our results offer insights into the likely effects and potential pitfalls of the recent flurry of new state-level initiatives to cover uninsured individuals. California's proposal mirrored some aspects of the Massachusetts plan by imposing combined

\footnotetext{
${ }^{5}$ There is limited evidence on the likely long-run effect of the availability of more generous subsidies. The Appendix discusses increased availability of low-cost policies: to the extent that these proliferate and drive net costs of insurance close to zero, there may be non-linear increases in take-up, as there is some evidence that take-up of free benefits is much higher than those with even modest copayments.
} 
individual and employer mandates, although it relies more on public insurance coverage expansion. Our estimates suggest that the individual mandate would cover more people than other policies alone, but the employer mandate could dampen employment among those employers not currently offering health insurance. Some of the distributional issues raised, such as low voluntary take-up among low-income working individuals, would be mitigated by the individual mandates. However, undocumented immigrants will continue to challenge states' efforts to cover uninsured individuals, and low-wage workers are at risk of lower employment rates as employers face higher payroll costs.

Many of the features discussed above are also present in Pennsylvania's recently announced Prescription for Pennsylvania, which includes an individual mandate for those whose income is over $300 \%$ of the poverty level, sliding scales for subsidized insurance coverage among employees of small firms unable to afford coverage, and a 3\% payroll tax for employers not providing health insurance coverage. Among individuals below 300\% of poverty, take-up will depend on the generosity of the sliding scales that the individuals face when purchasing coverage.

In late 2006, Indiana's governor, Mitch Daniels, proposed a plan to cover moderate-income individuals (up to $300 \%$ of poverty level) without access to employer-sponsored coverage. Indiana's plan would use cigarette taxes, Federal funds, and individual fees to allow individuals to buy into insurance coverage on a sliding-fee scale. Individuals buying into this plan would have a Health Savings Account (called a power account) and would receive free preventive care. The issue of take-up of subsidized coverage among moderate-income individuals also looms large for the success of this plan. Among uninsured individuals with family income under $300 \%$ of the poverty level, however, over $17 \%$ already have access to employer-sponsored coverage, so they would not be helped by the state plan. Even for the targeted individuals, it is unclear how many will take up coverage, and the coverage offered limited financial protection for individuals with catastrophic health care costs.

In his 2007 State of the Union address, President Bush proposed an overhaul of the tax treatment of health insurance. The proposed "Standard Deduction for Health Insurance" would replace the current preference for employer-sponsored health insurance with a flat deduction (for both payroll and income tax purposes) for anyone covered by private insurance, regardless of the source of the insurance or the size of the premium. The standard deduction would be $\$ 7,500$ for single coverage or $\$ 15,000$ for family coverage. Like a flat tax credit, this would substantially lower the cost of obtaining insurance for most people, but would be of highest value for people in the highest tax brackets. Unlike a non-flat credit or deduction that depended on the cost of the policy, it would give the same tax benefit for the purchase of low-cost policies as high-cost 
policies. This policy also leaves open the questions of take-up among low-wage workers with limited tax liability.

The value of different approaches to insurance expansion ultimately depends on policy priorities; tax credits and public insurance expansions generate the most redistribution, while mandates achieve the biggest overall reduction in the number of uninsured individuals at the risk of negative labor market consequences.

The feasibility of each approach depends on the environment in which it is pursued. Medicaid expansions may not be feasible among states struggling to cut, rather than increase, budgets. For these reasons, states will closely watch the success of current Medicaid waivers including cost containment strategies. Employer mandates meet with strong political backlash from business interests in all states, although perhaps less with more progressive business communities. Mandates in Massachusetts and those proposed in California and Pennsylvania may not withstand Employee Retirement Income Security Act (ERISA) challenges. Tax credits achieve redistribution, but at the greatest taxpayer expense, and would require an accompanying individual mandate to achieve a significant reduction in the number of uninsured individuals.

\section{Why don't expansions insure more people?}

The poorest working families are not the primary beneficiaries of any of the approaches examined here. Those in households earning less than $100 \%$ of the federal poverty level would experience little change in insurance coverage, although a portion of them would benefit from redistribution through tax credits or Medicaid expansions. The low insurance coverage among the poorest families stems partly from the fact that most uninsured workers work part-time and thus are not covered by most employer mandates. In addition, many lowincome workers are eligible for public insurance but do not take it up. Similarly, the increase in insurance coverage in response to tax credits is likely to be low due to low take-up.

Finally, a large fraction of the working poor may not be eligible for tax credits or public insurance because of their immigration status, yet the health and financial impact of uncompensated care is substantial in states with high immigrant populations. According to the March 2005 Current Population Survey, about one-third of uninsured workers with incomes below 300\% of the federal poverty level were not United States citizens. How policy-makers evaluate options depends on whether covering this population is one of their policy goals. To address the gaps in coverage for the poorest families, an individual mandate, extensions of employer mandates to cover part-time workers, or the loosening of 
restrictions for non-citizen eligibility for Medicaid benefits might change the composition and share of low-income individuals accessing health insurance.

\section{Limitations}

Our findings should be interpreted in light of several caveats. First, we have presented analyses of three stylized approaches to insurance expansion, but other strategies, including combinations of approaches currently being pursued by several states, are possible and might achieve desired outcomes more effectively.

Second, there are other potential labor market effects not considered explicitly in our simulation. For example, some researchers estimate that a large number of firms might alter the way they hire in order to avoid regulations that apply to firms over a particular size, such as 25 workers (Yelowitz, 2006). Regulations on employers could also accelerate an ongoing trend toward contingent workers who would not be covered by these regulations (Swartz, 2006). Thus, low-wage workers providing services even for large, relatively high-wage firms, may fail to benefit from employer-sponsored insurance. Potentially worse, those previously employed and receiving employer-sponsored coverage might be replaced by workers at firms not subject to employer mandates.

Finally, we estimated the changes in public and private spending based on typical insurance currently provided through private and public and group and non-group purchasers, but the cost and generosity of many insurance plans might change in response to policy changes. States may scale back optional Medicaid benefits, or purchasing pools paired with mandates may encourage highdeductible health plans, both of which have lower actuarial value. In these cases, the value of insurance coverage enjoyed by the insured and the costs of providing it may fall. Thus, our estimates may overstate changes in public and private spending, as well as the potential redistribution to those affected by each expansion approach.

\section{Conclusion}

States grappling with the growing number of uninsured individuals face tradeoffs between approaches that expand coverage most broadly with potentially negative labor market consequences, market-based approaches that redistribute dollars but are likely to insure relatively few, and expansion of public coverage that offers moderate gains in insurance coverage and redistribution, with moderate deadweight loss. Our findings suggest that no single approach helps the working poor in exactly the ways policy makers might hope. To the extent that states are motivated to help uninsured individuals in poor working families, health reforms 
must find ways to include those unlikely to take up optional policies, and states must address the challenge posed by uninsured workers and dependents likely to be excluded from policies (based on part-time status, firm size, or immigration status). Although a combination of the policies under debate and some of the innovative approaches being pursued by states offer the promise of expanded access to affordable insurance, advocates and policy makers should consider the full range of economic costs and distributional concerns when designing health insurance expansions.

\section{Technical Appendix to "State and Federal Approaches to Health Reform: What Works for the Working Poor?”}

The following tables and text provide details on the tax credit analyzed in the paper, the source of parameter estimates used to estimate who is covered by insurance policies, and the sensitivity of our estimates to the choice of key parameters. Table A1 provides detail on the proposed tax credit used in the simulations. Table A2 gives a detailed description of the parameter estimates used in the simulations presented in the text, including the source of each estimate and ranges in the literature. 


\begin{tabular}{|c|c|c|c|c|c|c|}
\hline \multirow[t]{3}{*}{ Table A1 } & \multicolumn{6}{|c|}{ Tax Credit Schedule } \\
\hline & \multirow[b]{2}{*}{$\begin{array}{l}\text { Single } \\
\text { filer }\end{array}$} & \multicolumn{5}{|c|}{ Other filer with insurance policy covering: } \\
\hline & & 1 adult & $\begin{array}{l}1 \text { adult \& } \\
1 \text { child } \\
\end{array}$ & $\begin{array}{l}2 \text { adults } \\
\text { no child }\end{array}$ & $\begin{array}{l}2 \text { adults \& } \\
1 \text { child }\end{array}$ & $\begin{array}{l}2 \text { adults } \& \\
2+\text { children }\end{array}$ \\
\hline $\begin{array}{l}\text { Maximum Adjusted Gross } \\
\text { Income that is eligible for } \\
90 \% \text { of premium up to cap } \\
\text { Range over which credit } \\
\text { phases out from } 90 \% \text { to } \\
50 \%\end{array}$ & $\begin{array}{l}\$ 15,000 \\
\$ 15,000- \\
\$ 20,000\end{array}$ & $\$ 25,000$ & $\$ 25,000$ & $\$ 25,000$ & $\$ 25,000$ & $\$ 25,000$ \\
\hline Phaseout range to $0 \%$ & $\begin{array}{l}\$ 20,000- \\
\$ 30,000\end{array}$ & $\begin{array}{l}\$ 25,000- \\
\$ 40,000\end{array}$ & $\begin{array}{l}\$ 25,000- \\
\$ 40,000\end{array}$ & $\begin{array}{l}\$ 25,000- \\
\$ 60,000\end{array}$ & $\begin{array}{l}\$ 25,000- \\
\$ 60,000\end{array}$ & $\begin{array}{l}\$ 25,000- \\
\$ 60,000\end{array}$ \\
\hline Maximum value of credit & $\$ 1,000$ & $\$ 1,000$ & $\$ 1,500$ & $\$ 2,000$ & $\$ 2,500$ & $\$ 3,000$ \\
\hline $\begin{array}{l}\text { Maximum cost of eligible } \\
\text { insurance policy }\end{array}$ & $\$ 1,111$ & $\$ 1,111$ & $\$ 1,111$ & $\$ 2,222$ & $\$ 2,778$ & $\$ 3,334$ \\
\hline Maximum adults & 1 & 1 & 1 & 2 & 2 & 2 \\
\hline Maximum children & 0 & 0 & 1 & 0 & 1 & 2 \\
\hline
\end{tabular}


Table A2

Simulation \& estimate needed

\section{Employer Mandate}

Average cost of single employer- \$4,024 sponsored health insurance coverage, 2005

Average cost of family employersponsored health insurance coverage, 2005

Average cost of coverage per private \$8,009 worker with ESI

\section{Parameter Estimates}

Estimate

Source

(Kaiser/HRET, 2005)

(Kaiser/HRET, 2005)

Authors' calculations based on 2005 CPS estimate that $41.9 \%$ of insured private workers at firms with $>25$ workers have single coverage and the rest have family coverage, and Kaiser/HRET (2005) survey estimates of average cost of policies

(Poterba, 1995)

compute costs of unvalued benefits

Effect of a $10 \%$ increase in health insurance premiums on:

- Aggregate probability of being $-1.2 \%$ employed

- Hours worked per employee $\quad-2.4 \%$

- Wages $-2.3 \%$

(Baicker, and Chandra, 2006)

(Baicker, and Chandra, 2006)

(Baicker, and Chandra, 2006)

\section{Medicaid Expansion}

Fraction of eligible adults and children 13\% who will take up Medicaid coverage

Fraction of newly insured who drop .35 prior health insurance coverage (crowd-out)

(Lo Sasso, and Buchmueller, 2004) The highest estimates of take-up ( 25\%) from Cutler and Gruber (1996) apply to pregnant women, a group likely to have higher take-up than many individuals targeted by current Medicaid expansion proposals.

Midpoint of range of estimates (.2 to .5) in the literature, in (Blumberg, Dubay, and Norton, 2000; Cutler, and Gruber, 1996; Dubay, and Kennedy, 1996; Shore-Sheppard et al., 2000; Lo Sasso, and Buchmueller, 2004; Yazici, and Kaestner, 2000) 


\title{
Table A2 continued $\quad$ Parameter Estimates
}

\begin{tabular}{lll} 
Simulation \& estimate needed & Estimate & Source \\
\hline $\begin{array}{l}\text { Cost of Medicaid per non-disabled } \\
\text { child in } 2000(\$ 2005)\end{array}$ & $\$ 1,343^{\mathrm{a}}$ & (U.S. House of Representatives, 2004) \\
Cost of Medicaid per non-disabled & $\$ 2,204^{\mathrm{a}}$ & (U.S. House of Representatives, 2004)
\end{tabular}

adult in 2000 (\$2005)

Average cost of single employersponsored health insurance coverage, 2005

Average cost of family employer- $\$ 10,880$

$\$ 4,024$

(Kaiser/HRET, 2005)

sponsored health insurance coverage, 2005

Average cost of coverage per private $\$ 7,899$ worker with ESI

\author{
(Kaiser/HRET, 2005)
}

Authors' calculations based on 2005 CPS estimate that $43.5 \%$ of all private workers have single coverage and the rest have family coverage, and Kaiser/HRET (2005) estimates of average cost of policies for 2005

Deadweight loss of taxes

.30

(Poterba, 1995)

\section{Tax Credits}

Take-up elasticity, or the (\% change in -.10 uninsured $) /(\%$ subsidy). If the take-up elasticity is -.10 , a tax credit providing a $50 \%$ subsidy to individuals would reduce the number of uninsured among target populations by $5 \%$.

Fraction of eligible and previously 3.8\% uninsured population who take up tax credit

Average non-group premium for single $\$ 2300$ coverage

Average non-group premium for family $\$ 4400$ coverage
Based on (Congressional Budget Office, 2005; Dorn et al., 2005; Marquis et al., 2004; Gruber, 2004). These estimates range from -.02 to .16

Authors' estimates using above price elasticity and March 2005 CPS.

Based on (AHIP Center for Policy and Research 2005).

Based on (AHIP Center for Policy and Research 2005).

Poterba, 1995

Deadweight loss of taxes

.30

All costs in 2005 dollars

a. 2000 estimates inflated to 2005 dollars 


\section{Sensitivity analyses of the choice of parameter estimates}

Some of the estimates used in the analysis are either controversial or based on relatively scant empirical evidence. For example, the crowd-out estimates from the literature range from a low of .17 to a high of .49. Table A3 shows how estimates change when the lowest and highest crowd-out estimates are substituted for the midpoint crowd out estimate used in our baseline simulation. The ranking of health reforms in terms of which is most effective at reducing the number uninsured, and which has the highest level of public spending per newly insured, or the largest change in private spending per newly insured remain unchanged for a wide range of crowd-out estimates. The labor market effect rankings of each expansion approach are also unchanged by differences in the parameter estimate. This sensitivity analysis highlights an unusual tension between crowd-out, which policy typically tries to minimize, and labor market effects. For Medicaid expansions, a higher rate of crowd out, while depressing the number newly insured and increasing the public costs per newly insured, carries larger positive employment effects.

\section{Sensitivity analysis of labor market parameter estimates}

A second consideration is the sensitivity of our results to the estimates in Baicker and Chandra (2006), the only available evidence of employment effects based on a within-state longitudinal analysis directly addressing the potential endogeneity of health care costs. If the true labor market response to health care costs were half of those estimated in Baicker and Chandra (2006), one would simply halve the employment effects shown in the bottom panel of table A3. For the lowest crowd out estimate, the employment effects of a Medicaid expansion would be much more modest, with an increase of about 40,000 workers, 48,000 hours worked per week, and $\$ 2.85$ billion in wages. Similarly, the negative impact of the employer mandates would be half as big.

Third, our principal simulation of the tax credit approach to insurance expansion uses the average price of insurance for single and family coverage in the non-group market to model the reference plan (\$2,300 for single coverage and $\$ 4,400$ for family coverage). In most areas, however, there are high-deductible and other low-cost plans available that might appeal to many buyers in the nongroup market. As a sensitivity analysis we examine the implications of the tax credit policy if individuals purchase insurance from health plans offering low-cost health savings account plans with high-deductibles (HSA-compatible plans) rather than the average plan. 


\begin{tabular}{|c|c|c|c|c|c|}
\hline \multirow[t]{2}{*}{ Change In: } & \multirow[t]{2}{*}{$\begin{array}{l}\text { Employer } \\
\text { Mandates }\end{array}$} & \multicolumn{3}{|c|}{$\begin{array}{c}\text { Medicaid } \\
\text { Expansions by crowd-out estimate: }\end{array}$} & \multirow[t]{2}{*}{ Tax Credits } \\
\hline & & .17 & .35 & .49 & \\
\hline Take-up by previously insured & NA & 1.3 million & 2.7 million & 3.7 million & 11.6 million \\
\hline Number newly insured & $13,030,547$ & 6.4 million & 5 million & 3.9 million & 1.5 million \\
\hline Percent reduction in uninsured & $28.6 \%$ & $14.8 \%$ & $11.6 \%$ & $9.1 \%$ & $3.4 \%$ \\
\hline Private spending & $\$ 40.6$ billion & $-\$ 4.0$ billion & $-\$ 8.3$ billion & $-\$ 11.6$ billion & $-\$ 6.4$ billion \\
\hline \multicolumn{6}{|c|}{ Labor market effects per $10 \%$ reduction in uninsured } \\
\hline $\begin{array}{l}\text { Change in: } \\
\text { Employed workers } \\
\text { (\% change) }\end{array}$ & $\begin{array}{c}-235,000 \\
(-.39)\end{array}$ & $\mathrm{b}$ & $\mathrm{b}$ & $\mathrm{b}$ & c \\
\hline $\begin{array}{l}\text { Hours worked/week } \\
\text { (\% change) }\end{array}$ & $\begin{array}{l}-18.8 \text { million } \\
(-.77)\end{array}$ & b & b & $\mathrm{b}$ & c \\
\hline $\begin{array}{l}\text { Annual wages } \\
\text { (\% change) }\end{array}$ & $\begin{array}{c}-\$ 20.8 \text { billion } \\
(-.69)\end{array}$ & $\begin{array}{l}\text { \$2.7 billion } \\
(0.24)\end{array}$ & $\begin{array}{c}\$ 6.9 \text { billion } \\
(0.33)\end{array}$ & $\begin{array}{l}\text { \$12.8 billion } \\
(0.68)\end{array}$ & c \\
\hline $\begin{array}{l}\text { a - Estimates not shown in this tab } \\
\text { employer mandate and tax credits are } \\
\text { b - Given the ambiguous sign of labo } \\
\text { these are set to equal zero. } \\
\text { c - Employment and hours might ris } \\
\text { workers would likely decline emplo } \\
\text { change in cash wages results from wa }\end{array}$ & $\begin{array}{l}\text { are unchanged by } \\
\text { inaffected by the cr } \\
\text { market effects acco } \\
\text { if employers were } \\
\text { er-sponsored insura } \\
\text { ses adjusting upwar }\end{array}$ & $\begin{array}{l}\text { changes in the } \\
\text { owd-out figure, b } \\
\text { mpanying tax cre } \\
\text { more willing to }\end{array}$ & $\begin{array}{l}\text { rowd-out paramet } \\
\text { it are shown for co } \\
\text { lits, and the expec } \\
\text { hire low wage wo }\end{array}$ & $\begin{array}{l}\text { er used in calculat } \\
\text { mparison. } \\
\text { ation that these are } \\
\text { rkers eligible for } \mathrm{N}\end{array}$ & $\begin{array}{l}\text { Figures for th } \\
\text { ivial in magnitude } \\
\text { dicaid (since thes } \\
\text { to be small. Th } \\
\text { ake up Medicaid }\end{array}$ \\
\hline
\end{tabular}


We use alternative premium information from two sources. First, America's Health Insurance Plans (the health plan trade organization) reported that the average premium for single coverage in the non-group market for the most popular HSA-compatible plan in January 2006 was \$1,121, \$1,914, and $\$ 3,157$ for subscribers aged 20-29, 30-54, and 55-64 respectively. For family coverage, premiums for the most popular plan were $\$ 2,507, \$ 3,951$, and $\$ 5,690$ for subscribers aged 20-29, 30-54, and 55-64 respectively. Based on those eligible for the tax credit, the population-weighted average premium for these HSA-compatible plans are \$1750 for single coverage and \$3935 for family coverage, only slightly lower than the average non-group market plan.

Second, Feldman and colleagues (Feldman et al., 2005) simulated the growth in HSA-compatible plans under a number of policy scenarios using data from eHealthinsurance.com. Their simulations use the average premium for a 40year-old non-smoking male for a plan with a $\$ 3,500$ deductible $(\$ 7,000$ for family coverage). The premiums for these HDHP plans are $\$ 1,233$ for single coverage and $\$ 2,724$ for family coverage. In Table A-4 below, we compare key results of the tax credit simulation under the three sets of alternative premiums. The numbers of newly insured and public spending are similar between baseline estimates and estimates using premiums reported by America's Health Insurance Plans. The number newly insured increases by roughly $70 \%$ in the model using the premiums from Feldman et al. (2005) compared to the baseline estimates. The deadweight loss rises modestly using the Feldman et al. (2005) estimates, about $7 \%$.

Under a range of reasonable assumptions about the premiums of eligible plans taken up by the newly insured, the tax credit approach yields many fewer newly insured and much higher public spending per newly insured than the employer mandate or Medicaid expansion. Moreover, we note that the increased numbers of newly insured and lower costs per newly insured associated with the simulations using the lowest premium estimates come at a cost of reduced coverage (i.e., high deductibles and possibly coinsurance).

\begin{tabular}{lcrr}
\hline Table A4 & \multicolumn{3}{c}{$\begin{array}{c}\text { Tax credit insurance effects for individuals up to } \mathbf{\$ 4 0 , 0 0 0} \\
\text { and families up to } \mathbf{\$ 6 0 , 0 0 0} \text { of adjusted gross income } \\
\text { assuming different types of insurance policies }\end{array}$} \\
\cline { 2 - 4 } & $\begin{array}{r}\text { Baseline (average) } \\
\text { health insurance } \\
\text { premium estimates }\end{array}$ & $\begin{array}{r}\text { AHIP-reported } \\
\text { HSA/HDHP } \\
\text { premiums }\end{array}$ & $\begin{array}{r}\text { Feldman et al. } \\
\text { HSA/HDHP } \\
\text { premiums }\end{array}$ \\
\hline Newly insured & 1.5 million & 1.9 million & 2.6 million \\
Deadweight loss & $\$ 2.7$ billion & $\$ 2.8$ billion & $\$ 2.9$ billion \\
\hline
\end{tabular}




\section{References}

AHIP Center for Research and Policy. (2005). "Individual Health Insurance: A Comprehensive Survey of Affordability, Access, and Benefits,” available online at http://www.ahipresearch.org/pdfs/Individual_Insurance_Survey_Report826-2005.pdf, accessed May 30, 2008.

Baicker K. and Levy H. (2005). "Employer Health Insurance Mandates and the Risk of Unemployment," Washington, D.C.: Employment Policies Institute.

Baicker K. and Chandra A. (2006). "The Labor Market Effects of Rising Health Insurance Premiums,” Journal of Labor Economics 24(3): 609-34.

Blumberg L.J., Dubay L., and Norton S.A. (2000). "Did the Medicaid Expansions for Children Displace Private Insurance? An Analysis Using the Sipp," Journal of Health Economics, 19(1):33-60.

Cogan J.F., Hubbard R.G., and Kessler D.P. (2005). "Healthy, Wealthy, and Wise," Washington D.C.: The AEI Press, and Stanford, California: The Hoover Institution.

Congressional Budget Office. (2005) "The Price Sensitivity of Demand for Nongroup Health Insurance,” Washington D.C.: The Congress of the United States.

Cutler D.M. (2002) "Employee Costs and the Decline in Health Insurance Coverage," Cambridge, MA: National Bureau of Economic Research Working Paper \#9036.

Cutler D.M. and Gruber J. (1996). "Does Public Insurance Crowd out Private Insurance?,” Quarterly Journal of Economics, 111(2):391-430.

Dorn S., Alteras T., and Meyer J. (2005). "Early Implementation of the Health Coverage Tax Credit in Maryland, Michigan, and North Carolina: A Case Study Summary," New York: The Commonwealth Fund, available at http://www.cmwf.org/usr_doc/806_dorn_earlyimplementationhct.pdf. Accessed April 14, 2008.

Dubay L.C. and Kennedy G.M. (1996). "Revisiting the Issues: The Effects of Medicaid Expansions on the Insurance Coverage of Children," The Future of Children, 6(1):152-61.

Etheredge L. M. (2006). "Massachusetts Reform Plus President Bush's Tax Credits: A National Model?,” Health Affairs, 25 (2006):w444-6. 
Feldman R., Parente S., Abraham J., Christianson J., and Taylor R. (2005). "Health Savings Accounts: Early Estimates of National Take-Up," Health Affairs, November/December:1582-91.

Glied S.A., Hart J., and Giorgi G. (2007). "Consider It Done? The Likely Efficacy of Mandates for Health Insurance," Health Affairs, 26(6):1612-21.

Glied S., Remler D.K., and Zivin J.G. (2002). "Inside the Sausage Factory: Improving Estimates of the Effects of Health Insurance Expansion Proposals," Milbank Quarterly, 80(4):603-35, iii.

Gruber J. (1994). "The Incidence of Mandated Maternity Benefits," American Economic Review, 84(3):622-41.

Gruber, J. (2004). "Tax Policy for Health Insurance," Cambridge, MA: National Bureau of Economic Research Working Paper \#10977.

Gruber J. and Krueger A.B. (1991). "The Incidence of Mandated EmployerProvided Insurance: Lessons from Workers' Compensation Insurance,” In: Bradford D. (ed), Tax Policy and the Economy, $5^{\text {th }}$ ed. Cambridge, MA: MIT Press.

Gruber J. and Washington E. (2005). "Subsidies to Employee Health Insurance Premiums and the Health Insurance Market," Journal of Health Economics, 24:253-76.Kaiser Family Foundation. "States Moving Toward Comprehensive Health Care Reform,” available at http://www.kff.org/uninsured/upload/1420_09.pdf. Accessed February 28, 2008.

Kaiser Family Foundation. "Health Care and the 2004 Elections: the Uninsured," available at http://www.kff.org/uninsured/7155.cfm. Accessed June 8, 2007.

Kaiser/HRET. "Employer-Sponsored Health Benefits Annual Survey," available at http://www.kff.org/insurance/7315/index.cfm. Accessed June 16, 2005.

Klerman J.A. and Goldman D.P. (1994). "Job Loss Due to Health Insurance Mandates,” Journal of the American Medical Association, 272:552-6.

Lo Sasso A.T. and Buchmueller T.C. (2004). "The Effect of the State Children's Health Insurance Program on Health Insurance Coverage,” Journal of Health Economics, 23:1059-82.

McDonough J.E., Rosman B., Phelps F., and Shannon M. (2006). "The Third Wave of Massachusetts Health Care Access Reform," Health Affairs, 25 w420-31.

National Conference of State Legislatures. (2006). "Health Insurance," Highlights: State Health Notes, 27(464):1-3.

Poterba J. (1995). "Government Intervention in the Markets for Education and Health Care: How Much and Why?,” In: Victor Fuchs, ed. Individual and Social Responsibility, Chicago, IL: University of Chicago Press. 
Shore-Sheppard L., Buchmueller T., and Jensen G., (2000). "Medicaid and Crowding Out of Private Insurance: A Re-examination Using Firm-Level Data," Journal of Health Economics, 19(1): 61-91.

Summers L. (1989). "Some Simple Economics of Mandated Benefits," American Economic Review, 79(2): 177-83.

Swartz K. (2006). "Reinsuring Health: Why More Middle-Class People Are Uninsured and What Government Can Do.” New York: Russell Sage Foundation Press.

U.S. House of Representatives, Committee on Ways and Means. (2004). 2004 Green Book, Washington, D.C.: United States House of Representatives.

United States Department of the Treasury. (2005). "General Explanations of the Administration's Fiscal Year 2006 Revenue Proposals," Washington, D.C.: U.S. Department of the Treasury.

Yazici E.Y. and Kaestner R. (2000). "Medicaid Expansions and the Crowding out of Private Health Insurance," Inquiry, 37(1):23-32.

Yelowitz A.S. (2006). "The "Fair Share for Health Care Act and New York's Labor Market.” Washington, D.C.: Employment Policies Institute 